\title{
Ainda existe a Universidade? Um retrato da universidade hodierna ${ }^{1}$
}

\author{
Jorge Olímpio Bento \\ Professor Catedrático Jubilado da Universidade do Porto
}

Resumo

O texto evidencia a crise da universidade, apreciada de vários ângulos, tendo por base a vivência do autor. A abordagem dá voz à necessidade de reinventar a Universidade, escrita com letra maiúscula.

Palavras-chave: universidade, crise, renovação, reinvenção.

\section{Abstract \\ Is there still a University? A portrait of the university today}

The text highlights the crisis of the university, analyzed from various angles, based on the author's experience. The approach gives voice to the need to reinvent the University, written in capital letters. Keywords: university, crisis, renovation, reinvention.

\section{Resumen}

Todavía existe la Universidad? Un retrato de la universidad de hoy

El texto evidencia la crisis de la universidad, teniendo en cuenta varios ángulos, con base en la vivencia del autor. El enfoque da voz a la necesidad de reinventar la Universidad, escrita con letra mayúscula.

Palabras clave: universidad, crisis, renovación, reinvención.

$1 \quad$ Este artigo foi mantido em português de Portugal. 


\section{Introdução: um olhar inquieto e 'circunstancial'}

A Universidade não tem que salvar o mundo, mas tem que se salvar a si mesma! Porém, está apodrecendo na teia que as circunstâncias lhe armaram. Enamorou-se delas, perde-se nelas e faz de conta que não se apercebe de nada. Foge às obrigações, volta as costas à missão original, trai e comete suicídio.

Os seus membros também não se salvam, se prescindirem de ver e questionar o óbvio, de dar testemunho do retrato que surge no olhar inquieto e desiludido.

A crítica e a divergência são de importância vital. Sempre, particularmente nas épocas em que a razão não passa de um débil lume, e não facilita a percepção da queda em várias formas de insensatez e irracionalidade.

Muito da espessa neblina, que nos cerca, decorre da falta de explicitação, quando não do encobrimento, de posições e opções. Está assim anunciado aquilo que me traz a este palco, a trama que venho representar, o essencial das afirmações e provocações com que quero incomodar e fatigar o leitor.

A Universidade transforma-se, pouco a pouco, num anão; vai definhando a justificação para continuar a escrevê-la com letra maiúscula. Dolorosa e paradoxalmente, hoje não podemos esperar atitudes edificantes de uma instituição criada para ser um dos poderes e referências espirituais da sociedade. Apaga-se nela a consciência dessa obrigação, e aumenta a cegueira da traição. Muitos universitários agem como extraterrestres de si mesmos, renunciam ao exercício do intelecto, à transparência das palavras e condutas; engrossam o grupo dos ladinos, peritos em driblar os princípios que apregoam.

Poderá soar a exagero, mas a Universidade parece imersa num sono de morfina; não se incomoda por estar a ser arregimentada e desfigurada para benefício dos interesses e perversões desta hora. Conformou-se aos ditames e receitas da agenda ultraliberal.

Não enterremos a cabeça na areia e não nos demitamos de denunciar. Dizer 'não' a tanta coisa escabrosa é tornar-se um alvo a abater. E equivale a arrostar com a acusação de pessimismo. Isso não intimida. Recuso alinhar com um otimismo que assenta na mania de sustentar que tudo está bem, quando está mal, que tudo está a ser feito para um fim melhor, quando serve intuitos inconfessos.

Não é aceitável fechar os olhos aos meios que estão na ordem do dia e aos fins 
aonde eles conduzem. Sirvamo-nos das palavras para interpelar os atropelos, para aliviar a nossa culpabilidade. Como diz Frei Bento Domingues (2011): “Os tempos estão perturbados, os tempos estão difíceis, são tempos desgraçados (...) Não são os outros e só os outros os verdadeiros culpados da nossa situação e não são eles os únicos a ter de mudar."

A partir da década de 80 do século passado, o ensino superior entrou numa convulsão. Os malefícios do domínio da economia pela finança e da política por ambas são notórios na universidade. Chamemos as coisas pelo nome: o neoliberalismo assentou arraiais na organização e orientação da vida universitária, na docência, na investigação e em tudo o que lhe diz despeito. Mais, na universidade dos rankings, o livre debate de ideias foi praticamente interditado. O pensamento crítico foi enterrado numa cova escondida e funda, de difícil acesso. Quem o cultiva torna-se marginal ao sistema.

Pode a universidade atual ser designada 'Universidade’? Não pode; é uma escola técnica superior. O que oferece aos estudantes é mera 'instrução funcionalizante'.

\section{Um novo jargão: a universidade 'empresa’}

Nas sessões solenes da universidade ouvem-se oradores que são um Deus-nos-acuda! Os papagaios do CEO de um grupo económico desatam a universidade das funções de Casa de Formação do espírito e intelecto da Humanidade, e amarram-na à cadeia de proveitos financeiros. Imitam os patrões do futebol que o rotulam de 'indústria’ para 'justificar’ a desvinculação dos ideais do desporto.

Não basta ficar perplexo; requer-se desmontar o cenário e enfrentar a sinistra realidade. A ideologia totalitária do neoliberalismo invadiu o campus universitário, com efeitos opiáceos, inibidores da perceção das consequências. Há quem não veja o óbvio!

A universidade está a ser desfeita reduzida a empresa concorrente de outras empresas similares. As arengas centram-se nos consórcios e negócios, na enfatização de produtos comerciais, nas demonstrações de lucros. O resto é despiciendo e sacrificado a toda a engrenagem do figurino empresarial. Os afetos e as amizades, a qualificação e a fruição da vida são descartáveis. O colega não é companheiro de caminhada; na carreira só interessa o meu sucesso, o do outro ou o seu infortúnio não me diz nada. 
A nova bíblia manda conformar a instituição e as pessoas aos mandamentos da agitação e frenesim sem pausa, da produtividade e competitividade, da aceleração e voracidade. Quem resista ao modelo e às suas tábuas-de-lei não pertence a este tempo; ou muda ou é posto à margem. A inquisição voltou e trouxe a paz dos cemitérios!

A universidade está imersa numa grave crise de discernimento e posicionamento. Os princípios e valores, constituintes da sua matriz, não passam de um enfeite de palavras atiradas ao vento. A linguagem do economês e 'financês' sobrepõe-se a todas as outras. É uma caixa-de-ressonância do mercado e das suas alienações e manipulações.

Para que serve a universidade hodierna? É criada ou diarista para todo e qualquer serviço. Compraz-se em orgasmos com o acessório; e descura o cimeiro e essencial.

Não há Universidade sem pensadores e sem tomada de posições sobre os problemas de cada era, para além do tempo e das circunstâncias. Se assim não for, ela fica refém do relativismo e do niilismo, e ausente da Humanidade e Sociedade. Se não escapar aos ventos do senso-comum, sobre ela cairá a acusação formulada por Oscar Wilde (1854-1900): “Todo o crime é vulgar, exatamente como toda a vulgaridade é um crime."

Ora, a queda na vulgaridade não está para vir, já veio; ou seja, a universidade comete crime contra si mesma, e escreve-se agora com letra pequena.

\section{Do manicómio das métricas, rankings e quejandos}

A comunicação social inunda-nos, a toda a hora, com a droga dos rankings de cursos e universidades. Que fazer? Sacudir os ombros ou cartografar a manobra analgésica?

As bitolas instituídas para avaliar as instituições de educação, formação e investigação, os docentes e pesquisadores são parte do sofisticado arsenal de estupefacientes, de técnicas de cosmética e propaganda, promovido pela globalização neoliberal. Não são indicadores fiáveis da qualidade do labor desenvolvido, do bem e mal-estar sentido; enviesam problemas de fundo, devido à falta de escrutínio esclarecido. A credibilidade e integridade académicas murcham, envenenadas pela prosápia e procura de vantagem e visibilidade. Alastra a autoalienação destrutiva. Eis o manicómio elevado a catedral! 
Com a cotação em alta está a 'quantidade' dos 'papers'. ${ }^{3}$ A serventia da maioria deles, se fossem pesados e não contados, não teria peso algum na balança da fecundidade! O dever da produtividade gerou a feira da vaidade; esta não corresponde a uma genuína utilidade. O produtivismo não casa com brilhantismo (BERG; SEEBER, 2016).

O rei vai nu, vestido com as penas do autoengano. De nível similar é a relevância de linhas de pesquisa conformes a modismos falhos de consistência conceptual. E também o celebrado 'fator de impacto'. Este reduz-se ao número das citações que os autores dos artigos fazem uns dos outros; e não ao impacto para além dos muros académicos, na orientação dos que não são 'cientistas' e tanto precisam do seu apoio.

Haja parcimónia! As agências de 'rating' das universidades, nomeadamente o 'ranking' da Times Higher Education ou o Academic Ranking of World Universities, este elaborado em Xangai, escondem o essencial. Nos lugares cimeiros surgem universidades dos EUA e algumas do Reino Unido. As pessoas olham para o escalonamento e não se interrogam acerca do que ele contém.

As universidades norte-americanas não foram sempre no pelotão da frente. A maioria delas é de ínfima qualidade. A dita 'excelência', agora creditada a uma elite, pertenceu a universidades europeias durante séculos; foi perdida no período do fascismo e do nazismo, que levou à fuga dos melhores cérebros para os EUA.

Nas últimas décadas, poucos países europeus apostaram seriamente em elevar a qualidade das universidades. Muitos países, sobretudo os periféricos, submeteram o ensino superior a 'reformas' ditadas por motivações mercadológicas. Propalam o desejo de melhorar a eficiência, mas reduzem drasticamente o investimento. O resultado é a profunda crise em que se encontra o sistema, e donde não mais vai sair airosamente.

A crise é particularmente evidente em Portugal, embora não se restrinja às paragens lusitanas (DE MASI, 2017). Os apertos financeiros são crescentes. O envelhecimento da corporação docente e a dificultação da renovação são dados sobejamente conhecidos. A qualidade do cumprimento da missão universitária tende a diminuir inexoravelmente. Jovens talentosos são forçados a emigrar; os que logram ingressar na docência universitária vivem situações de gritante precariedade. Para colocar a

3 Para dar uma imagem real da tragicomédia em cena, imaginemos o seguinte: No concurso para uma vaga de professor na área de música aparecem dois candidatos. Um é autor de uma composição com valia afim, p. ex., à da Nona Sinfonia de Beethoven; o outro é autor de várias peças com nível igual ao da música 'brega' ou 'pimba'. Quem ganha o concurso? O segundo! 
cereja no topo do bolo, não são benquistos os pensadores e as ideias de rutura com a situação vigente. O resultado do reformismo é um autêntico 'genocídio' ou 'epistemecídio' intelectual e cultural.

Enquanto nas badaladas universidades dos EUA não falta dinheiro para o funcionamento e a inovação, por cá registam-se:

- Instalações, laboratórios e equipamentos aquém do exigido;

- Progressão do ambiente inculto;

- Aumento da burocracia e das condições de trabalho mortificantes;

- Falta de contacto dos professores com os estudantes: mal se conhecem e só se 'encontram' nos exames;

- Recurso a jovens doutores, na docência e investigação, com contratos temporais e salários ridículos (inferiores aos dos mais baixos funcionários não docentes), porém obrigados a trabalhar como se fossem professores de carreira;

- Utilização de estudantes de doutoramento na lecionação, não para os 'treinar', mas porque o orçamento impede a contratação de docentes.

Muita gente parece cega e não ver o óbvio; mas tem cura, conquanto tome os remédios adequados. Um deles é a leitura de autores que pensam e respiram fora da caixa oficial. Para quê? Para abrir um caminho não trilhado, em vez de prosseguir no mesmo. A saída do ambiente mórbido é, desde logo, um sinal de sanidade.

\section{Da doença e do embuste da 'competitividade'}

Quando falamos de 'saúde', as palavras subentendem, em regra, os familiares, amigos e vizinhos. Não olhamos para as instituições de formação e pesquisa; devíamos fazê-lo. Estão elas ‘saudáveis’? Não estão provocando danos na saúde dos servidores?

O linguajar, que se implantou na universidade, incuba vírus perigosos. Um dos termos mais usados por mentes pueris e secas de ideais, mas com apetite voraz, é o flamejante vocábulo 'competitividade'. Do que se trata? A enfatização da competência não passa de embrulho de uma abominável agressividade. Coloca o ardiloso verniz da normalidade cívica nos comportamentos de sujeitos que aceitam todo o tipo de exigências, incluindo calcar e esmagar colegas e 'amigos' de ofício (e de gabinete!), para satisfazer o instinto carreirista. 
A perversão da teoria evolucionista de Darwin projeta o indivíduo humano como ser de 'necessidade' e não de 'liberdade'. Consagra e idolatra a 'competitividade': 'competir' na permanente luta de sobrevivência com os outros, os semelhantes e dissemelhantes. Porém, o Ser Humano faz coisas 'livres' da necessidade: arte, música, poesia, pintura, desporto, teatro, etc.

O mandamento da 'competitividade' (uma adulteração do sentido da 'competição’ e do agonismo, herdados da paideia grega) é abjeto e inconcebível na escola e universidade. Inferniza as duas. Instala um clima de desconfiança e perseguição do outro!

$\mathrm{Na}$ universidade estamos a 'educar' e 'formar' quadros com mentalidade de eliminação e destruição. Custa a reconhecer a verdade! Quadros destinados a cuidar da vida (p. ex., médicos) adquirem inclinações para arrasar os outros.

Acresce que a 'competitividade' entranha a submissão e o conformismo: 'formamos' os 'melhores' para se conformarem e vergarem, para estudar e fazer o que interessa ao sistema, despojados de apetência para o criticar, transformar e melhorar.

Digamos sem rodeios, é sordidez e loucura total ter que destruir os laços com os outros para ser Eu! Esta guerra insana de competição por rendimento e supremacia provoca transtornos da personalidade: elimina o 'Eros' da gratificação proveniente do Outro. Por detrás da miragem da afirmação e liberdade, medram a autoagressão, o abatimento e o esgotamento (HAN, 2018). Edificante, como bem se vê!

A este propósito vale a pena trazer à colação o pensamento de Sócrates (470399 a.C.) sobre a educação. O filósofo chamou 'maus' aos indivíduos desprovidos da aptidão para conviver. Ora, no nosso tempo abunda a maldade e escasseia aquela capacidade. Ou seja, o alvo maior da educação é hoje a formação da prontidão para a convivência, para olhar em volta e verificar que outros Eus moram ao nosso lado. Somos entes de coabitação, naufragamos na solidão.

Eis aqui plasmada a categoria mor da educação, renegada pela universidade hodierna! Isto não pode ser calado e subvalorizado; é hediondo, exige ser discutido e alterado.

Damásio (2017) alerta, de maneira dramática, para a premência da educação e qualificação dos sentimentos. A desordem das coisas traduz o caos e a 'bancarrota espiritual e moral', existencial, cultural e social, resultante da desordem sentimental. É com os sentimentos que construímos a personalidade, a subjetividade e a consciência, governamos ou desregramos a vida. Se não os educarmos e qualificarmos, 
matar-nos-emos, cada vez mais, uns aos outros.

'Educar' e 'qualificar' os sentimentos é um imperativo à escala universal e individual, para vigiar a subjetividade, alertar a consciência e civilizar a conduta. Deve ser o metro-padrão da organização e orientação da escola e universidade, visando a regeneração da sociedade e da Humanidade. E porquê? Porque a pulsão da morte vive uma era de euforia, e tende a esmagar a pulsão da vida.

'Educar' os sentimentos é sublimar a violência e a bestialidade, expressas em palavras e atos de amordaçamento, acinte, ameaça, insulto, ódio, intolerância, raiva, represália, vingança, exclusão, humilhação e subjugação do Outro.

Não chega que a universidade, para lavar as mãos da sua cumplicidade com a desordem dos sentimentos desta era, faça um ato de contrição; tem que mudar o rumo da ação. ${ }^{4}$

\section{Da 'empregabilidade’ e da 'preparação’ para a vida}

Esta bandeira, tão agitada pela acreditação e propaganda dos cursos universitários, é mais uma das medonhas falácias em vigor. Para além de soterrar as balizas da educação, escamoteia as mudanças no panorama profissional e existencial.

Como será o mundo quando as crianças, que agora iniciam a escolaridade, concluírem o percurso da educação? Que profissões terão desaparecido e surgido no entretanto? Continuará a haver as ocupações, os ofícios e serviços de agora, e com o mesmo perfil? Quais os bens materiais e imateriais requeridos? Que princípios enformarão o cenário civilizacional, cultural, laboral, etc. no médio prazo?

As indagações querem significar a insensatez de centrar na 'empregabilidade’ a

4. A necessidade de alterações na oferta formativa é manifesta. Com a leitura de romances e poesia, com a contemplação de obras de arte, com a audição de peças musicais, aprimoramos os sentimentos, nomeadamente os papeis que eles cumprem:

- 'Inteligir' (entender, compreender e escolher) os factos da vida no emaranhado da sua confusão, veneração, confusão e efusão;

- Monitorização, observação, controlo e reflexão do drama ou comédia da existência, do que corre bem ou mal no sentido mais amplo do termo;

- Ajustamento dos procedimentos;

- Motivação para percorrer os caminhos que nos falta andar, e para chegar às metas onde queremos chegar. 
reflexão sobre a missão da escola e da universidade. É impossível antecipar o futuro e o leque de competências e habilidades para responder às respetivas exigências. Hoje e sempre, a referência axial do labor educativo reside na formação da Pessoa, Humana, Divina, Ética, Livre. Não há outro empreendimento tão exaltante. São as Pessoas, não os escorpiões, insetos, ratos, serpentes e vermes, que criam um mundo novo e melhor.

A prescrição de 'educar', 'formar' e 'preparar' para a vida obriga a perguntar o que se entende por 'vida': a totalidade existencial ou tempo do trabalho? (MASI, 2017).

Com efeito, somente um oitavo da existência futura das crianças e adolescentes de hoje será gasto no trabalho. É para essa fração que se orientam a educação e formação? E o resto, aquilo que Aristóteles (384-322 a.C.) colocava do centro da atenção educativa e de onde provém a palavra escola ( 'Scholé) não conta?

A 'Scholé' era o lugar do ócio e tranquilidade, da admiração do elevado e nobre, da bondade e generosidade, para lá do útil e necessário. Assumia a 'bios theoretikos', o 'theorein' e o 'teorizar': cultivar a calma e a demora no pensar e contemplar as 'coisas' superiores e virtuosas, o fulgor da verdade e da beleza no seu máximo esplendor.

A mestria técnica e instrumental não converte um sujeito medíocre em 'excelente’ profissional. Não se vai lá sem a competência para a ‘compreensão’ e o ‘entendimento’. Torga (1907-1995) define de modo cristalino: “Compreender (...) é explicar o que se nos opõe, valorizar o que até aí não tinha valor dentro de nós. O diverso, o inesperado, o antagónico, é que são a pedra de toque dum acto de entendimento.” (1986).

É a formação que possibilita:

- Interrogar, alargar o olhar, enxergar e visar o distante, almejar a amplitude, a diversificação e a imensidão do espaço;

- Perceber o eterno que é sempre novo, o perdurável, o intangível, o simbólico, o não revelado, os a priori iluminadores e avaliadores dos a posteriori;

- Sentir atração pelo belo e bom, pela amabilidade, amenidade e convivialidade, pela serenidade, suavidade e moderação, pela empatia, simpatia, partilha e identificação com o Outro, com o seu lugar e vivência.

Sim, chama-se 'formação' à aspiração à verdade que não consente o mentir, associa meios e fins, valora as ações em função das consequências, encoraja a escolher as boas e rejeitar as más! Não é mais importante essa função? Se é, quem substitui a 
escola e a universidade nesse desígnio?

Creio que, por força da incerteza do futuro e da aceleração das mudanças, a formação universitária deve privilegiar a 'criatividade’, entendida como síntese da ‘imaginação’ e da 'concretude’. A primeira cuida da ‘idealização’, da propensão para voar, criar, inovar e projetar. A segunda, dos métodos para eleger os caminhos e rumos a seguir. Isto implica atribuir, pelo menos, tanta importância à fecundação da inspiração, da decisão, flexibilidade, invenção científica e estética como aos conhecimentos e habilidades de ordem técnica e prática.

Ao invés, a instrução renuncia à noção de ‘formação’ (Bildung), que serviu de referência a Wilhelm Humboldt (1767-1835) para alicerçar a Universidade Moderna. Olvida a obrigação de formar os estudantes para a ubiquidade e a cidadania planetária, de os dotar com visão e linguagem universal.

A ‘instrução’ está prenhe da obsessão de orientar e preparar os estudantes, como se o mundo e a existência fossem uma guerra não convencional, disputada com artimanhas e simulações, para que eles cortem nela o maior número de cabeças possível e saiam dela ilesos e até com refinamento da astúcia de armar ciladas e passar a perna aos outros. Quanto a fornecer aos estudantes saberes e temas de reflexão para melhorar a vida na totalidade, para tecer juízos críticos sobre os roteiros da sociedade e enraizar a emulação solidária, sobre isso não há pronunciamento.

Na prática, a universidade abdicou da formação integral dos estudantes; produz sujeitos unidimensionais, fortes e soberbos com os fracos e subalternos, cobardes e dóceis com os chefes, exterminadores dos colegas, induzidos a supervalorizar o produtivismo, e a subestimar o autoaperfeiçoamento espiritual, a introspeção, a reflexão, a amizade, o amor, o bem-estar, o sentido de comunidade, etc.

Com tanta ênfase posta no 'empreendedorismo’, nas estratégias para o 'sucesso’ e para a liderança, esquece que os clientes e funcionários de qualquer organização são pessoas. Como é que alguém pode entender de negócios, se não entender de pessoas e se ele próprio não for a melhor Pessoa que é possível ser?!

Para desfazer equívocos: valorização da qualificação profissional, sim! Acompanhada da formação dos jovens para uma vida feliz, para não se afundarem no pasmo. A escola e a universidade não servem apenas para preparar para o trabalho, mas sim para instigar a viver à altura do melhor do espírito do tempo e das suas aspirações, 
para acompanhar e reclamar o avanço civilizacional. A cultura é e será sempre um meio para esse fim.

Isto não está ao alcance de uma universidade contaminada pela incultura, por salários ridículos, estruturas burocráticas, condições de estudo e trabalho penosas e asfixiantes. Um retrocesso, porquanto nas academias atenienses, segundo relata Platão (428/427-348/347 a. C.), "conviviam professores bem remunerados e alunos muito motivados de ambos os sexos.”(DE MASI, 2017, p. 492).

O autor de $A$ República considerava a educação "o mais importante dos esplêndidos bens que os melhores homens recebem”. Devia instituir e incentivar o apego à virtude, "o amor e o desejo de se realizar como cidadãos, de maneira a saber governar e ser governados segundo a justiça”. Pela educação, todo o cidadão podia ser inferior ou superior a si mesmo; ou seja, ele dependia da formação adquirida.

Platão distinguia a 'educação negativa', voltada para o lucro, da 'educação positiva', orientada para a virtude. Por sua vez, Aristóteles diferenciou a educação voltada para a atividade e a voltada para o ócio, outorgando primazia à segunda.

Em suma, o fim da educação não se prendia ao fortalecimento da vontade de dominar os outros, mas ao enaltecimento da felicidade de viver, ao cultivo do ócio, da alma, do corpo, do intelecto, dos sentimentos e virtudes (DE MASI, 2017).

A formação renascentista seguiu as pegadas gregas. Acrescentou o objetivo de libertar o estudante da influência de um único mestre, mas manteve o de assentar a prática numa sólida base teórica. Leonardo Da Vinci disse isso claramente: "Estude primeiro a ciência e depois a prática nascida dessa ciência. Os que se apaixonam pela prática sem ciência são como timoneiros que entram no navio sem timão ou sem bússola”. (DE MASI, 2017, p. 494).

A universidade hodierna contraria isto. Os estudantes têm diversos professores; mas não recebem a influência de várias orientações. Preside a tudo e a todos a cartilha do senso comum neoliberal: a visão monolítica do mundo e da vida.

\section{Da 'massa crítica' e da transdisciplinaridade}

Uma das mais estapafúrdias propostas programáticas é a da junção de 'massa crítica', visando atingir um superior nível de saber. Para tanto advoga-se a fusão de faculdades, institutos e organismos afins. 
A novidade surge, é certo, nas fronteiras de áreas complementares. Este milagre não resulta da adição de especialistas; requer que cada um seja 'transdisciplinar' e evolua nessa direção, por formação e vontade próprias. Só assim se aguça o intelecto.

A 'massa' não tem nada de 'crítico'. Representa a degradação do pensamento e da razão. Basta reparar na conduta de qualquer bando e horda ou tribo do futebol. Como assinala Henry David Thoreau (1817-1862), "a massa nunca se eleva ao padrão do seu melhor membro; pelo contrário, degrada-se ao nível do pior”. ${ }^{5}$

O excesso e embriaguez do idêntico estreita o raciocínio, é obeso e comatoso, mais do mesmo, amorfo, indiscernível, insípido e uniforme. Falta-lhe o contrário dialético, a dimensão redentora da Alteridade. Fecha-se ao saber (HAN, 2018).

A mesmidade é hoje o traço marcante das linhas de investigação. Os assuntos e temas são repetidos e replicados ad nauseam. O défice de criatividade e originalidade conduz à vacuidade e à esterilidade. Um vazio gritante!

Se não queremos engordar os desvarios, sejamos aprendizes do desassossego e da dúvida, abertos ao desconhecido. O ‘agir' renovador requer pensamento atrevido; a vinda do pensar proscrito e desassombrado que nos faz estranhar a realidade, e nos encoraja a conceber outra relação com ela.

Esse pensar estimula a romper com a ditadura do idêntico. Incita a descobrir a sabedoria das velharias, a implodir a tristeza e vileza de um quotidiano sem chama e ousadia (HAN, 2018).

Pensar é grátis! Impliquemo-nos no advento de uma era que ponha cobro à proliferação patológica do numérico, do mesmo e igual; e restaure a amabilidade, a comunicação e a proximidade, a empatia e a solicitude, o cuidado e o zelo, a deferência e a graça, a hospitalidade e a disponibilidade para a Alteridade. Na peregrinação sobre a Terra só alcançamos grandeza e identidade no Outro, e não no reino esconso e sufocante do eu.

\section{Do estado e descaso das palavras}

A palavra (tal como o livro) anda pelas vielas da amargura, sujeita a tratos de polé. É agredida, enlameada e deformada no espaço universitário. Vive num clima de 
asfixia e horror. Muitos escrevem a linguagem do 'globish'. Poucos dominam o idioma pátrio, o sabem embelezar e honrar. É uma raridade preciosa a dissertação escrita em português escorreito; e uma exceção a aula onde o verbo adquire esplendor para encantar e iluminar quem o ouve. Hoje não se fala, linguareja-se!

A acusação é pesada, mas não difamante: a universidade é inimiga do livro e da palavra alta portuguesa. Desde o início da licenciatura até ao término do doutorado, quantos livros lê um estudante? Lerá algum livro de cultura geral? Quantas monografias e dissertações passariam no crivo da norma linguística?

Isto não é um pormenor insignificante; é um 'pormaior' determinante! O estado e a forma das palavras ditas ou escritas revelam o nível do pensamento e das ideias. Mais ainda, através da laboração na linguagem labora-se no aprimoramento do pensamento. O grau performativo da linguagem traduz a maneira de entender o mundo. A lista de implicações e reciprocidades podia ser estendida. As palavras retratam quem as escreve e diz, tal como formulou Octávio Paz (1914-1998): "Pela palavra, o homem é uma metáfora de si próprio.” Uns levantam voo, outros afogam-se em pântanos.

Voltaire (1694-1778) estava cheio de razão: “Aprender várias línguas é questão de um ou dois anos; ser eloquente na sua própria exige a metade de uma vida.”

A palavra é malquista na universidade. É preciso andar de candeia acesa nos corredores e salas, como Diógenes de Sinope (412-323 a.C.), o 'Cínico', à procura de quem a diga de maneira a contagiar e incendiar os estudantes. $\mathrm{O}$ ideal do 'Homem de saber ampliado’ e discurso aceso, com muito para contar, tão exaltado por Homero, Kant e outros, está despindo as vestes da academia. Por este andar, não vem longe o dia em que será quase impossível encontrar um professor capaz de proferir uma alocução, uma conferência ou palestra à altura de suscitar o encantamento e entusiasmo da plateia.

Urge ressuscitar, celebrar e entronizar a Palavra alada, limpa, luminosa e incandescente.

\section{Ciência: da admiração à desilusão}

A ciência é uma extraordinária criação da Humanidade. Não é a única, nem a maior. Todas se atam a uma finalidade sublime: o alargamento da imaginação e o florescimento do encanto numa existência condenada à finitude. 
O campo da ciência é assaz fértil em frutos magníficos, indo desde o alívio de dores, a cura de males e o prolongamento da vida até ao melhor conhecimento do universo. Este é ‘multiverso', ou seja, integra uma multitude de dimensões e facetas.

O método científico esclarece muito, mas não tudo; e não detém a prerrogativa de decretar o que há para explicado. Não poucos dos seus cultores encaram-no como crentes inflamados pelo afã religioso e metafísico. Comportam-se como polícias e vigias, como se a razão científica fosse totalitária e excludente de outros olhares. E assim transformam a ciência em 'tudologia' e credo de fanáticos: realizam autos de fé, negam e suprimem alternativas para tentar reduzir a fome de sentido dos humanos (GIANETTI, 2016).

É verdade que a ciência ajuda a iluminar, mas não sacia a fome de sentido, existente desde tempos imemoriais. Não diz nada sobre ela, se for árida e mirrada de poética, de êxtase e espanto. E é isto que alastra na universidade; o deserto avança e enche-lhe de areia os olhos, a boca, o coração e a alma. O pragmatismo e o utilitarismo vigoram; os estudantes de doutorado são funcionalizados em especialistas de técnicas de pesquisa, em vez de ser formados como cientistas no genuíno sentido do termo.

De resto, nas instituições universitárias não escasseiam 'triunfadores' científicos, com marcas visíveis de défice de sentido, de depressão e sensação de vazio, de desamparo, frivolidade e inutilidade. Por lá transitam vidas infantilizadas que se consomem em si mesmas, sem pontes para o mistério existencial, para algo maior e superior.

Afinal, falta a humildade científica para valorar a amplidão da visão ‘universitária', para estimar, respeitar e fomentar outras formas de racionalidade, para compreender o ‘multiverso' do universo, e admitir o desconcerto do saber finito pela ignorância infinita.

\section{Cegueira e perplexidade: Sereia muda e Centauro deformado}

Domenico De Masi olha para a universidade hodierna e vê nela uma 'sereia muda' e um 'centauro deformado' (DE MASI, 2017). A constatação suscita perguntas que atingem o nosso rosto como um vento gelado e cortante.

De que janela e com que luz quer a universidade velar a vinda do futuro? Com que tipo de futuro deseja ter cumplicidade?

Almeja ser uma casa da erudição, da espiritualidade e da sabedoria ou de am- 
plificação do ‘mainstream’ ideológico? A sua nova e exaltante vocação é a de 'fábrica de papers?! É esta a sua missão cimeira, e autónoma das outras?

Sendo a investigação fundamental, livre e sistemática, indispensável para o avanço da ciência e para o bem-viver dos povos, como valoriza aquela exigência e se distancia das linhas de pesquisa impostas por modas e pressões das redes do império editorial?

Pressente-se na universidade predisposição para a autoavaliação da sua perversão, com a deriva pragmática e reverenciadora do putativo mercado?

Estas questões podem ser resumidas numa: Perante quem e perante o quê somos universidade e académicos? A pergunta é simples. Experimentemos fazê-la, pensá-la e responder-lhe! Na resposta encontramos a história de cada um, a da academia e a da Humanidade (a de Caim e Abel, de Dalila e Sansão, de Brutus e Júlio César, de Judas e Jesus). Ela põe à mostra: omissão e traição, deslealdade e oportunismo, inveja e cobiça.

A traição, mesmo que seja por incúria, ingenuidade, imperícia, irresponsabilidade e negligência, tem um efeito devastador: esvazia o traidor da essência do ser, anula-o como pessoa, atenta contra o que ele acredita ser.

A crise da universidade deriva do seu alheamento em relação ao decurso do mundo. É ocasionada pela cegueira de 'trevas brancas', de que nos fala José Saramago (1922-2010), na sua magistral obra Ensaio sobre a Cegueira. Os universitários têm olhos para ver, mas recusam-se a fazer uso deles, afetados por uma escuridão que provoca a rutura com a sua identidade. Perderam prestígio e protagonismo; deixaram-se 'encurralar' (no sentido literal do termo!) na nulidade.

As agências de notação financeira (rating) valoram de acordo com as conveniências e recomendações de quem lhes paga. Os pareceres dos escritórios de advogados seguem o mesmo padrão. Assim se impõe o modo de ver vigente.

Não é segredo algum: só enxergamos o que aprendemos a ver. Melhor dizendo, o olho vê apenas o que a mente está preparada para compreender. A instrução universitária em voga não prepara para ver a dominação iníqua do mundo. Deste jeito, a universidade abjura o cumprimento da função maior, justificativa da sua criação e existência.

Por isso tem fundamento o desabafo, fruto da constatação de factos: a Uni- 
versidade já não existe! Trai a Civilização e a Sociedade, os princípios do seu contrato civilizacional e social. Renunciou aos fins superiores e sublimadores do seu funcionamento. Contenta-se em ser uma escola técnica com estatuto de superior.

O espaço académico sofreu uma 'metamorfose epidémica'. A profissão docente (a bela e nobre profissão de formar pessoas) está doente. E muitos dos seus agentes não o estão menos; não sentem incómodo com o rumo da universidade, nem com o modo como exercem o seu labor. Estão naturalizados num papel que, eles sabem isso perfeitamente, origina um ambiente de exaustão.

Debaixo do tapete das desculpas, escondem-se a mediocridade e a perda da noção de dignidade. Não reagem à degradante situação. O professor universitário já não é o que era, afasta-se a passos largos do imaginário que edificou e habitava o seu mister. A extensão da decadência vê-se naquilo com que os atingidos se satisfazem. A perda é enorme; no entanto, é escasso o número dos que se erguem contra semelhante calamidade. Esta atitude contamina os estudantes.

Querem ou não os universitários reapossar-se do encargo de ‘intelectuais?? Reveem-se no cinismo cego e obsceno de uma sociedade líquida e impossível que alija, com toda a naturalidade, uma parte de si mesma? Estão ou não disponíveis para remover os dejetos da apodrecida imundície ‘competitiva' e ‘produtivista’ que, com o seu astuto e cobarde silêncio, fingem desconhecer e não ver?

A cobardia traça o destino do mundo e também o da universidade. Esta anda entretida numa dança de fogos fátuos, que confunde com o arco-íris. Quer manter o fogo do espírito, mas falta-lhe e deita fora a lenha para acender e alimentar essa fogueira.

\section{Conclusão: uma crise para durar}

1. Não se incorra no equívoco de confundir 'reformismo’ e renovação! O 'reformismo’ não almeja o progresso. Quer eliminar o que há de mais progressivo no legado recebido, e repor o obscurantismo desaparecido. É este o propósito.

A vida e as instituições exigem 'reforma' e recriação contínuas, mas não foi para as 'renovar' e 'melhorar' que foram advogadas e feitas reformas 'estruturais' nos últimos anos. É em nome da reposição de privilégios retrógrados, em benefício de coutadas privadas e em prejuízo do bem comum. A matriz neoliberal traz o diabo no ventre; muita gente incauta e de boa fé não se dá conta disso, bate palmas 
à propaganda enganosa.

2. A retórica universitária passou a ser inundada pela eficiência e pelos 'outputs', por pressões para adotar metodologias de gestão afins às empresariais. A universidade converte-se em empresa; verga-se ao managerialismo, incluindo os concursos para reitor e diretor. Quem não se sintoniza com a novilíngua da 'doce barbárie', não pertence a este tempo. As disciplinas e as vozes de teor humanista são convidadas a mudar de roupagem ou então sujeitam-se a ser atiradas para o caixote do lixo. ${ }^{6}$

A nova Jerusalém dos deslumbrados universitários está nos EUA, assinala Domenico De Masi com fina acuidade. Lá universidade e sociedade caminham de mãos dadas. Ambas enaltecem o mercado dito livre, mas, de facto, dominado pelos oligopólios e lóbis da finança e das indústrias. Quem vence a corrida são sempre os mesmos: os mais ricos, sabidos e ousados, sem escrúpulos e freios éticos, numa concorrência desleal que visa unicamente o sucesso e a hegemonia sobre os outros. Só há vencedores e perdedores: um jogo de soma zero.

3. É este o modelo que diversos países têm tentado copiar e implantar zelosamente nas universidades. Em Portugal e noutros países ocorre o que Domenico De Masi descreve de forma magistral: “a confusão normativa, a incapacidade organizacional e a falta de investimentos produziram um sistema (...) que deixou de ser latino e ainda não é americano, uma espécie de monstro mitológico confuso: uma sereia agora muda ou um centauro agora aleijado.”(DE MASI, 2017).

Não se pense que a crise é semelhante a uma ligeira e passageira indisposição. Trata-se de uma doença maligna. A incubação do vírus foi longa e ignorada. O doente parece em estado terminal; carece de cuidados extremos e onerosos. A regeneração é incerta, exige orçamentos fora do comum, tempo demorado e esforço intelectual suado.

Enfim, o 'reformismo’ do virar de século lançou o mundo universitário numa confusão. E isto influi para além do seu espaço, porquanto da universidade depende tudo: o futuro de um país, o dos cidadãos, a edificação da liberdade. A configuração

6 Para perceber melhor a crise que lavra na universidade e atinge os seus docentes, recomendamos a leitura dos seguintes artigos:

- $\quad$ Barnett. (2008);

- Bailey (2008). 
da universidade, a sua orientação e o seu funcionamento retratam fielmente o modo como se perspetiva o país, a vida das pessoas, o mundo e a Humanidade.

4. De quem é a culpa da situação? De inúmera gente e de ninguém em particular. É das sucessivas reformas e contrarreformas levadas a cabo por forças políticas com distintas designações, todas elas apostadas em impor o modelo de pendor neoliberal, copiado dos EUA, sem cuidar de atender às condições, circunstâncias e tradições do país.

É dos reitores que, agrupados no seu Conselho (o CRUP, no caso português), se reúnem e emitem declarações sem teor de contestação real das determinações governamentais. Simulam confrontos com o ministro do setor, mas raro é aquele que quebra o verniz da docilidade, quiçá esperando receber um dia o convite para a pasta ministerial.

A culpa é de reitores (novamente no caso português), escolhidos ao abrigo do RJIES-Regime Jurídico das Instituições do Ensino Superior. A maioria deles jamais acederia ao cargo, se não tivesse sido roubado à academia o direito de eleger o Reitor (portugal, 2007). ${ }^{7}$

Reitores com défice de legitimação democrática têm muitas dificuldades em dar passos contrários às forças que os diminuem a eles e apequenam a universidade. Eles e muitos diretores de Faculdade não compreendem que não há soluções técnicas para problemas políticos. Contentam-se com poderes de fachada, em ser donos de nada e com lutas de pobres e espertos para ver quem leva a melhor na partilha dos míseros orçamentos.

A culpa é também dos professores; deixam-se proletarizar e abdicam de engajamento numa reivindicação comum, de agir para além do horizonte do seu ego, de se colocar ao lado dos outros. Cada um age isoladamente, cuidando que isso o beneficia. Parecem indiferentes à degradação das condições de formação dos estudantes e de respeito pelos direitos destes a um ensino de qualidade. No entanto, não cessam

$7 \quad$ A Lei $n^{\circ}$. 62/2007, de 10 de setembro de 2007, estabelece o regime jurídico das instituições do ensino superior em Portugal, regulando designadamente a sua organização, a constituição e eleição dos titulares dos seus órgãos. O órgão máximo da universidade é o Conselho Geral; pode ter entre 15 a 35 membros e compete a ele a escolha do reitor, abrindo para o efeito um concurso. No caso da Universidade do Porto, o Conselho Geral é composto por 23 membros: 6 personalidades externas (uma das quais preside ao órgão), 12 docentes, 4 estudantes e 1 funcionário não docente. O RJIES está imbuído de uma orientação 'managerialista' e neoliberal; impôs uma redução drástica da participação democrática da comunidade académica no funcionamento das instituições. 
de enfatizar que a universidade existe para os estudantes. A cobardia e a hipocrisia, a falsidade e a mentira estão casadas em comunhão de bens.

5. Que ventos sopram hoje na universidade? Têm algo a ver com os que se evadiram da Caixa de Pandora? Há alguma inquietude em relação à possibilidade de correlação?

A universidade encontra-se mergulhada, mais ou menos em todo o mundo, numa crise de autonomia e independência, de identidade e consciência da sua missão. Não cumpre o múnus de intermediação entre o saber e os cidadãos. Abstém-se de chamar a si a apologia e proclamação das causas da Civilização, da Humanidade e da Sociedade. Usa o alfabeto serventuário de interesses e modismos impostos por forças e amos externos, sem crédito ético e moral. Troca as causas por coisas, o idealismo por servilismo.

Julgo que foi Octávio Paz (1914-1998) quem chamou à contemporaneidade “o inferno com ar-condicionado”. E a universidade hodierna o que é? Para onde caminha?

Só não vê quem não quer. Ela tem vindo a renunciar à letra maiúscula e à condição de instância de meditação, projeção e reflexão da sociedade, optando por advogar e seguir religiosamente os descaminhos e enganos desta era. Tornou-se instrumento orgânico, adota e propaga as ilusórias receitas da doutrina neoliberal.

Nunca, em qualquer regime político, se observou uma captura ideológica tão ardilosa, abrangente e indecorosa. $\mathrm{Na}$ torre da universidade ondula a bandeira da saudação e vassalagem ao suserano vigente. Uma vida com padrões de qualidade para todos e a renovação cultural e edificante da existência, tirando partido dos formidáveis avanços científicos e tecnológicos - isso não consta no programa da pequena universidade.

6. Estamos encalhados num modelo de sociedade e universidade. Sairemos dele, se o dermos por gasto e buscarmos a superação. Para isso é curial pensar o impensado. Ora os pensadores escasseiam, devido ao facto de a vita contemplativa ser "marginalizada em benefício da vita activa e de a inquietação hiperativa, a agitação e o desassossego atuais não se casarem bem com o pensamento”. Este, “em consequência de uma pressão temporal cada vez maior, tende a não fazer mais do que reproduzir o mesmo."(HAN, 2016, p. 129).

Nesta conjuntura não é o pensamento que rege o tempo. É este que dita e coman- 
da o pensamento, reduzindo-o a cálculo, e tornando-o efémero, frágil, volátil, sem contacto com o sólido e o duradoiro. Ao pensamento pertence a asa da liberdade, o luxo de se distanciar da necessidade, da visão única e estreita, do tempo e do espaço dados. Na hodierna 'fábrica universitária' imperam o calculismo, a incapacidade e o desprezo pelo pensar. O indivíduo contenta-se com o estatuto de animal laborans. Contrariando a tese de Hegel (1770-1831), ele é escravo si mesmo.

Desapegados de pensar, baralhados e imersos nos números, viciados nos índices e rankings, deitamos fora a utopia. Estamos reféns de coisa nenhuma, quase contentes por não ter que sonhar o lugar e a realidade inexistentes, mas possíveis.

O que é preciso para romper o colete de forças que comprime a universidade? Algo pequeno na formulação, porém assaz exigente na ação: coragem e lucidez!

Se as possuímos e não usamos, somos cobardes; se as não temos, somos carentes e dementes. Tanto num como no outro caso, não estamos à altura de cuidar de outrem; carecemos de alguém que cuide de nós. Logo, sejamos honestos, justos e rigorosos: o nosso lugar não é na academia; é num hospício!

7. Este é o meu retrato, sintetizado em palavras de repulsa e indignação, resultantes de lutas e posições assumidas na última dúzia de anos de uma carreira, que findou afogada num mar de decepção e desilusão.

A frustração sussurra-me nos ouvidos, na consciência, na boca e nas mãos a advertência da compositora musical Janis Joplin (1943-1970): “Nunca te vendas. És tudo o que tens.”

Até quando vai a comunidade académica suportar a menorização? Enquanto continuar imersa na apatia e distração, no alheamento e consentimento generalizados, e não acordar da anestesia, a universidade verá agravada a sua existência. Ninguém de fora virá em seu socorro!

Somente a insurgência consequente poderá trazer de volta a Universidade com letra maiúscula. Acordemos e clamemos por reinvenção! Recomeçar é a nossa obrigação. Por mais que nos afastemos do ponto de partida, o destino e o fado estão por cumprir. A condição de Sísifo impede a conclusão e perfeição; e impõe a tarefa de repetir o começo, de regressar ao princípio, de 're-partir' do zero. Acabar é começar. É do final que partimos para tentar de novo, falhar de novo, falhar melhor. Uma e outra vez. Sempre! 


\section{Referências}

BAILEY, Ralph W. Is the University in Ruins? Discussion paper number 2008-2. Birmingham: Institute for Economic Development Policy, University of Birmingham, 2008.

BARNETT, Ronald. Being an academic in a time-impoverished age. In: AMARAL, A.; BLEIKLIE, I.; MUSSELIN, C. (Eds). From governance to identity. Dordrecht: Springer, 2008. p. 7-17.

BERG, Maggie; SEEBER, Barbara K. The slow professor: challenging the culture of speed in the Academy. Toronto: University of Toronto Press, 2016.

DAMÁSIO, António. A estranha desordem das coisas: as origens biológicas dos sentimentos e da cultura. São Paulo: Companhia das Letras; 2018.

DE MASI, Domenico. Alfabeto da sociedade desorientada: para entender o nosso tempo. São Paulo: Objetiva, 2017.

DOMINGUES, Frei Bento. Virtudes para um mundo melhor. Público. p. 32, 13 mar. 2011.

GIANETTI, Eduardo. Trópicos utópicos. São Paulo: Companhia das Letras, 2016.

HAN, Byung-Chul. A expulsão do outro. Lisboa: Relógio D’Água Editores, 2018. p. 9-18.

HAN, Byung-Chul. O aroma do tempo. Lisboa: Relógio D’Água Editores, 2016.

TORGA, Miguel. O Alentejo. In: TORGA, M. (Ed). Portugal. 5a. ed. Lisboa: Coimbra, 1986. p. 119-29.

PORTUGAL. Lei n ${ }^{\circ}$ 62/2007. Que trata do regime jurídico das instituições de ensino superior. Diário da República. Lisboa, 10 ago. 2007. Disponível em: <http://dre.pt/ util/getdiplomas.asp?iddip=20073059>. Acesso em: 15 set. 2018.

Submetido em: 10-10-2018

Aceito em: 20-1 1-2018 